Postprint of Journal of Environmental Management, Volume 280, 15 February 2021, 111733

DOI: https://doi.org/10.1016/j.jenvman.2020.111733

\title{
BATCH MESOPHILIC ANAEROBIC CO-DIGESTION OF SPENT GOAT STRAW BEDDING AND GOAT CHEESE WHEY: COMPARISON WITH THE MONO-DIGESTION OF THE TWO SOLE SUBSTRATES
}

\author{
M.J. Fernández-Rodríguez ${ }^{1,2 *}$; N.F. Puntano1; J.M. Mancilla-Leytón ${ }^{3}$; R. Borja ${ }^{1}$ \\ ${ }^{1}$ Instituto de la Grasa (CSIC), Campus Universidad Pablo de Olavide. Edificio 46. Ctra. \\ de Utrera Km. 1, 41013, Sevilla, Spain. \\ ${ }^{2}$ Departamento de Sistemas Físicos y Naturales, Universidad Pablo de Olavide. Ctra.de \\ Utrera, km 1, 41013 Sevilla, Spain. \\ ${ }^{3}$ Departmento de Biología Vegetal y Ecología, Facultad de Biología, Universidad de \\ Sevilla, 41080, Sevilla, Spain
}

E-mail of the corresponding author*: mjfernandez@ig.csic.es

\begin{abstract}
Spent livestock bedding is a valuable resource for the production of green energy (methane) in rural areas. Comparison and evaluation of batch anaerobic digestion and co-digestion of different mixtures of goat straw bedding (SGSB) and goat cheese whey were carried out. Biochemical methane potential (BMP) tests of the 100\% SGSB, 95\% SGSB-5\% whey, 90\% SGSB-10\% whey, $85 \%$ SGSB-15\% whey and $100 \%$ whey were
\end{abstract}


found to be $423 \pm 7,354 \pm 9,371 \pm 2,293 \pm 1,274 \pm 2 \mathrm{~mL} \mathrm{CH}_{4} \mathrm{~g}^{-1} \mathrm{VS}$. Two different kinetic models were evaluated. The logistic model revealed a decrease in the maximum methane production rate $\left(R_{m}\right)$ from $34.7 \pm 1.5$ to $14.1 \pm 0.9 \mathrm{~mL} \mathrm{CH}_{4} \mathrm{~g}^{-1} \mathrm{VS} \cdot \mathrm{d}^{-1}$ when the percentage of whey in the mixture increased from 0 to $15 \%$ as a consequence of the increased ammonia released during the co-digestion of increased concentrations of whey. The lowest value for the maximum methane production predicted by the model (P) was found for $100 \%$ whey $\left(274 \pm 10 \mathrm{~mL} \mathrm{CH}_{4} \mathrm{~g}^{-1} \mathrm{VS}\right)$. A two-substrate model was applied to describe the evident existence of rapid and slowly degradable material. Regarding the hydrolysis kinetic constants predicted by this model, considerable increases in the rapid biodegradation stage $\left(k_{\text {rapid }}\right)$ were observed when comparing to the values found for the slow $\left(k_{\text {slow }}\right)$ biodegradation stage in all the cases tested. The increases between both constants rose from 5 to $42 \%$ when the percentage of whey increased.

Keywords: spent goat straw bedding; cheese whey; anaerobic co-digestion; methane yield; process kinetics; two-substrate model.

\section{INTRODUCTION}

According to Jurgilevich et al. (2016) it has been estimated that up to $30 \%$ of all food produced around the world is lost or wasted, and therefore, the extraction, transformation, distribution, use and recovery of the materials and energy of commercialized products should be managed in a cyclical fashion (Stahel, 2016; Rodrigues and Borges, 2020). The prevention, reduction and recycling entails a reduction in the waste generation (United Nations Development Programme 
(UNDP), 2016). At present, the linear industrial model of resource consumption "takemake-disposal" is inefficient and threatens competitiveness (Macaskie et al., 2019). In order to counteract this problem, in 2015, policies were implemented to design and innovate for a circular economy and to make better use of natural resources (Towards a circular economy: A zero waste programme for Europe, COM/2014/0398). EU's efforts is an essential contribution to the develop a sustainable, low carbon, resource-efficient and competitive economy. This transition is the opportunity to transform our economy and generate new and sustainable competitive advantages (Closing the loop - An EU action plan for the Circular Economy COM/ 2015/ 614).

The agricultural production have been strongly criticized not only for the high production of agricultural by-products, but also for the high demand for inorganic fertilizer materials, fuels, greenhouse gas emissions, etc., which increase the linear economy in the production system (Duque-Acevedo et al., 2020). In the case of livestock, its numbers have grown along with the human population due to the demand for protein of animal origin (Van Kernebeek et al., 2016). Consequently, a large amount of agricultural-livestock wastes are produced every year all over the world. Only a part of them are used, with the rest being unused and transformed into potential pollutants with high disposal costs. The main limitation for residues' producers is the lack of knowledge in alternative treatments (Foley et al., 2011; Rojas-Downing et al., 2017).

Last few years the reuse of pig and cattle by-products has been the focus of interest but no attention has been paid to small ruminants. More than 75,000 farms are dedicated to goats, $10 \%$ of which are dedicated to milk production. The Spanish goat sector is one of the largest milk producers in Europe (Spanish Agrarian Guarantee Fund O.A., 2020). 
Currently, one of the main challenges the livestock industry faces, especially goats, is to look for alternatives to the large amounts of effluents which are generated, particularly from stabled production systems. For years, herbivore dung has been used with crop stubble as organic matter for soils (Awodun et al., 2007; Holter, 2016). Although this organic matter can be incorporated directly into the soil, it is not recommended because of the presence of faecal coliforms and pathogens, which can produce infectious diseases (Jiang et al., 2015). Instead of providing directly the goat dung into the soil, composting is a simple technology for manure or spent straw bedding treatment. The final product of the process (compost) does not contain pathogens (De Corato, 2020). In deep-litter housing systems, spent straw bedding is usually employed to absorb excrements and urine, thus creating a solid waste rather than a liquid one (i.e. slurry). Such solid waste is soiled bedding that accumulates in the stables and which is referred to as spent bedding (Riggio et al., 2017) or spent straw if the latter is used for bedding material.

Dairy production species (cattle, sheep and goats) have an added problem such as the large amount of wastes that is generated from the dairy industry. Dairy industries have undergone huge growth in many countries due to the increasing demand for milk and milk products. It is generating high quantities of dairy effluent with high polluting power. Worldwide, dairy by-products of about 4-11 million tons are released into the environment every year, which is a serious danger for biodiversity (Ahmad et al., 2019). The world production of cheese whey is estimated at about 157 million tons (Macwan et al., 2016); to make $1 \mathrm{~kg}$ of cheese 7-8 kg of whey are generated (Carvalho et al., 2013). Traditionally, cheese whey was considered as a waste product and was disposed of by the cheapest possible method, e.g., fed to animals, spray irrigated onto land or treated as effluent (Fox et al., 2017). The dumping of whey is unacceptable today due to its potent 
polluting effect in environmental ecosystems, so treatment systems involving the proper disposal of whey have been taken more seriously (Macwan et al., 2016).

The disadvantages of the current use of the main by-products from goat farming together with the tightening of the current regulations on the application of slurry in soil (Royal Decree Royal 1078/2014; Regulation (EU) 1306/2013 European Parliament), and the lack of connection between livestock and agriculture, mainly due to the increasingly widespread use of inorganic fertilizers (Foley et al., 2011), require viable alternatives for the management of these by-products. The target is look for a costeffective way of recovering by-product. Numerous studies have focused on other techniques for the treatment and / or use of these by-products; recycling by-products not only avoids disposal costs and the environmental problems they cause, but also provides a recovery pattern for the sector (Feng et al., 2018; Van et al., 2020). In order to reduce the organic matter content of the wastes Biotechnological methods have been demostrate to be a good option (Carvalho et al., 2013; Islam Siddique et al., 2020). Therefore, anaerobic digestion (AD) presents a promising approach to the socioeconomic and environmental benefits (Martínez-Sabater et al., 2019). The use of $\mathrm{AD}$ for the treatment of organic wastes helps to reduce it as well as lower greenhouse gas emissions and produce renewable energy. (Joshi and Visvanathan, 2019).

A good alternative from an environmental and economic point of view would be the good treatment of waste generated in agriculture and dairy industries. Therefore, with the goal of promoting the circular economy model, the overall aim of this study was to evaluate and compare the biogas production of the main by-products from goat farm (spent goat straw bedding (SGSB) and cheese whey (whey) by subjecting them to AD and co-digestion, since they are produced in the same place and both need environmental compliance. Although there are quite a few research works that have 
anaerobically treated cheese whey (Mainardis et al., 2019; Gameiro et al., 2020), there are hardly any works that have used SGSB as substrate for anaerobic digestion (Riggio et al., 2017); and there are no research works on the co-digestion of both substrates. The use of these agro-industrial wastes for methane production can give rise to high biodegradability and therefore reduce their environmental impact (Islam Siddique et al., 2020).

Therefore, the specific aims of this study were: (1) to determine the biochemical methane potential (BMP) of the single spent goat straw bedding (SGSB) and goat cheese whey as well as of different mixtures of both substrates; (2) to determine the best co-digestion ratios of SGSB and whey to ensure a high methane production and stability of the process; (3) to develop a sigmoidal or logistic model in order to predict the BMP and to determine the kinetic parameters of the different processes assayed using the experimental results; (4) a two-substrate model was applied to report the presence of rapid and slowly degradable material in the wastes tested.

\section{MATERIALS AND METHODS}

\subsection{Anaerobic digestion substrates and inoculum}

SGSB and semi-soft goat cheese whey were used as feedstock for different anaerobic co-digestion mixtures as well as for the anaerobic mono-digestion of both substrates individually. SGSB was collected after two weeks of use from the Experimental farm center at the University of Huelva (Spain). SGSB is a mixture of straw and goat manure and is a very heterogeneous substrate. The whey was obtained from an artisan cheese factory in Huelva, Andalusia, Spain. Both substrates were stored separately at $-4{ }^{\circ} \mathrm{C}$ 
until use, always less than $48 \mathrm{~h}$. In order to characterize the SGSB and whey different chemical and elemental analyses were performed (Table 1).

The anaerobic inoculum was obtained from an industrial upflow anaerobic sludge blanket (UASB) reactor of a brewery factory located in Seville (Spain). The inoculum was chosen due to its high methanogenic activity, which was determined in previous anaerobic assays (Fernández-Rodríguez et al., 2019).

Some characteristics of the SGSB, whey and the inoculum used in the experiments are shown in Table 1.

Table 1. Characteristics of the spent goat straw bedding (SGSB), semi-soft goat cheese whey (whey) and the anaerobic inoculum used in the experiments. Where TS: total solids, VS: volatile solids, COD: total chemical oxygen demand, nd: not determined.

\begin{tabular}{llll}
\hline & SGSB & whey & Inoculum \\
\hline $\mathrm{TS}\left(\mathrm{g} \mathrm{kg}^{-1}\right)$ & $286.6 \pm 11.8$ & $57.3 \pm 3.8$ & $30.5 \pm 0.7$ \\
$\mathrm{VS}\left(\mathrm{g} \mathrm{kg}^{-1}\right)$ & $263.4 \pm 9.5$ & $51.4 \pm 3.8$ & $22.7 \pm 1.8$ \\
$\mathrm{VS} / \mathrm{TS}(\%)$ & $91.9 \pm 10.7$ & $89.7 \pm 3.8$ & $74.4 \pm 1.1$ \\
$\mathrm{COD}\left(\mathrm{g} \mathrm{O}_{2} \mathrm{~kg}^{-1}\right)$ & $301.0 \pm 1.7$ & $60.0 \pm 1.0$ & $32.8 \pm 1.1$ \\
$\mathrm{pH}$ & $\mathrm{nd}$ & $3.39 \pm 0.2$ & $7.24 \pm 0.1$ \\
$\mathrm{C} / \mathrm{N}$ & $21.0 \pm 0.4$ & $15.1 \pm 0.2$ & $7.7 \pm 0.5$ \\
& & & \\
\hline
\end{tabular}

\subsection{Experimental set up and procedure}


The effective volume of the reactors was $250 \mathrm{~mL}$. The inoculum to substrate ratio was 2 (VS basis) according to the literature recommendations (Mainardis et al., 2017). For each reactor containing $239 \mathrm{~mL}$ of inoculum, the amount of substrate needed to give the required inoculum to substrate ratio was added together with $239 \mu \mathrm{L}$ of trace element solution (Fernández-Rodríguez et al., 2019). As controls, three $250 \mathrm{~mL}$ batch reactors were supplied with the inoculum and trace elements solution but without the addition of substrate. The reactors were sealed and the headspace of each flask was flushed with nitrogen at the beginning of the assay. The produced biogas was passed through a $3 \mathrm{~N}$ $\mathrm{NaOH}$ solution to capture $\mathrm{CO}_{2}$; the remaining gas was assumed to be methane. The anaerobic digestion experiments were run for a period of c.a. 30 days until the accumulated gas production remained essentially unchanged.

Three replicates for each setting were carried out. Data were presented as means \pm standard deviations of the means $(n=3)$. The trials were performed at mesophilic temperature $\left(35 \pm 2{ }^{\circ} \mathrm{C}\right)$ in a multi-batch reactor system and the reactors were continuously agitated by magnetic bars at $440 \mathrm{rpm}$. Different co-digestion mixtures of SGSB and whey were tested: 95\% SGSB-5\% whey; 90\% SGSB-10\% whey; $85 \%$ SGSB-15\% whey. In addition, the digestion of single SGSB (100:0, only SGSB) and only whey (0:100, single whey) (VS basis) were also assessed.

\subsection{Analytical methods}

The substrates and inoculum were analysed previously to the beginning of the experiments. In addition, the digestates or effluents of each set of experiments were also analysed at the end of each experiment. The performed analyses were: Total solids (TS) and volatile solids (VS) were performed according to the Standard Method 2540E (APHA, 2012), soluble chemical oxygen demand (SCOD) was also determined 
following the standard method 5220D (APHA, 2012), using the closed digestion and the colorimetric method. Total chemical oxygen demand (COD) was analyzed as described by Raposo et al. (2008). $\mathrm{pH}$ and Total alkalinity (TA) were determined in fresh samples using a pH meter model Crison 20 Basic. TA was measured by $\mathrm{pH}$ titration to 4.3 (APHA, 2012). Total ammonia nitrogen (TAN) was measured by distillation and titration according to the Standard method $4500-\mathrm{NH}_{3}$ (APHA, 2012). $\mathrm{C}$ and $\mathrm{N}$ were determined through an Elemental Analyzer LECO CHNS-932 (Leco Corporation, St Joseph, MI, EEUU). Soluble parameters were determined after sample centrifugation (Eppendorf, $10000 \mathrm{rpm}, 10 \mathrm{~min}$ ) and filtration (glass fiber filter 47mm). The following formula was used to calculate the free ammonia concentration (Østergaard, 1985):

$$
\frac{\left[\mathrm{NH}_{3}\right]}{\left[\mathrm{TNH}_{3}\right]}=\left(1+\frac{10^{-\mathrm{pH}}}{10^{-\left(0.09018+\frac{2729.92}{\mathrm{~T}(\mathrm{~K})}\right)}}\right)^{-1}
$$

$\left[\mathrm{NH}_{3}\right]$ : free ammonia concentration; [ $\left.\mathrm{TNH}_{3}\right]$ : total ammonia concentration;

$\mathrm{T}(\mathrm{K})$ : Temperature in degrees Kelvin.

\subsection{Kinetic modelling}

\subsubsection{Sigmoidal or logistic model (4 parameters)}

The sigmoidal or logistic model (4 parameters) was applied to fit the experimental data of methane production during BMP tests. The sigmoidal or logistic model (4 parameters) is given by the subsequent equation (2):

$$
B_{2}=B_{0}+P /\left[1+\exp \left(-4 \cdot R_{m} \cdot(t-\Lambda) /(P+2)\right)\right]
$$

where $B_{2}$ is the cumulative methane production during the second stage $\left(\mathrm{mL} \mathrm{CH}_{4} \mathrm{~g}^{-1}\right.$ $\mathrm{VS}), B_{0}$ is the cumulative methane production at the start-up of the second stage $(\mathrm{mL}$ 
$\mathrm{CH}_{4} \mathrm{~g}^{-1}$ VS) and should approximately coincide with the cumulative methane at the end of the first days of digestion; $P$ is the maximum methane production obtained $\left(\mathrm{mL} \mathrm{CH}_{4}\right.$ $\left.\mathrm{g}^{-1} \mathrm{VS}\right) ; R_{m}$ is the maximum methane production rate $\left(\mathrm{mL} \mathrm{CH}_{4} \mathrm{~g}^{-1} \mathrm{VS} \cdot \mathrm{d}^{-1}\right)$ and $\Lambda(\mathrm{d})$ is the lag time. In addition, $\mathrm{R}^{2}$, error $(\%)$ and standard error of estimate (S.E.E.) were determined to evaluate the fit and precision of the results. Error was defined as the difference in percentage between the experimental accumulated final methane production and that predicted by the model.

\subsubsection{Two substrate kinetic model}

The methane production data from the batch $\mathrm{AD}$ tests were also modelled by a twosubstrate kinetic model. In this model, all the trial assessed (100\% SGSB, 100\% whey and the different co-digestion mixtures) were composed of a rapidly biodegradable substrate type and a slowly biodegradable substrate type; SGSB and whey were present in all the mixtures assayed at the beginning of the tests and degraded according to the hydrolysis rate constant of the respective fractions (Rao et al., 2000; Bai et al., 2016; Scarcelli et al., 2020). This two-substrate kinetic model is given by equation 3:

$\left.B=B_{\text {rapid }}\left[1-\exp \left(-k_{\text {rapid }} * t\right)\right]+B_{\text {slow }}\left[1-\exp \left(-k_{\text {slow }} * t\right)\right]\right)$

where $B$ is the methane production $\left(\mathrm{mL} \mathrm{CH}_{4} \mathrm{~g}^{-1} \mathrm{VS}\right)$ after a time $t(\mathrm{~d}), B_{\text {rapid, }} B_{\text {slow, }}$, and $k_{\text {rapid }}$ and $k_{\text {slow }}$ correspond to the maximum methane yield ( $\mathrm{mL} \mathrm{CH}_{4} \mathrm{~g}^{-1} \mathrm{VS}$ ) and hydrolysis kinetic coefficient $\left(\mathrm{d}^{-1}\right)$ of the rapidly and slowly biodegradable fraction, respectively. In order to evaluate the performance of the model, the determination coefficient $\left(\mathrm{R}^{2}\right)$ and the standard error of the estimate (SEE) were calculated, which also allowed for obtaining additional information about the goodness of fit of the experimental results for this model. If the model accurately predicts the kinetic 
parameter, $\mathrm{R}^{2}$ should be close to 1 and the SEE, which is a measure of the accuracy of predictions, tends to be low.

\section{RESULTS AND DISCUSSION}

\subsection{Elemental and chemical analyses of the substrates and anaerobic inoculum}

The composition of the SGSB mainly depends on the time that the SGSB remains in the barn, since it will determine the contents of manure and straw in the substrate (SanchisSebastiá et al., 2020). The heterogeneity of the substrate is also due to the thickness of the bed, which is determined as a combination of several layers in different stages of degradation (Sanchis-Sebastiá et al., 2020). Table 1 shows the main characteristics of both substrates. The TS content of the SGSB was $286.6 \pm 11.8 \mathrm{~g} \mathrm{~kg}^{-1}$. Despite the substrate heterogeneity, similar TS values were reported by Riggio et al. (2017) (298 \pm $\left.8 \mathrm{~g} \mathrm{~kg}^{-1}\right)$. The VS/TS ratio of SGSB was $91.9 \pm 10.7 \%$, which was slightly higher than that reported by Riggio et al. (2017) (84.4 $\pm 2.7 \%)$. Riggio et al., (2017) also reported that the VS content of the different animal straw beddings was in the range of 82.3 to 88.9\%. This high value of VS demonstrates the high biodegradability of the substrate and its potential to be used as a substrate for $\mathrm{AD}$. The C/N ratio of SGSB used in this study was 21, which is inside of the range reported by Riggio et al. (2017) (20-28).

Whey is also a heterogeneous substrate, mainly composed of proteins, minerals and carbohydrates (Escalante et al., 2018; Mostafa-Imeni et al., 2019). Whey presented a typical acidic $\mathrm{pH}$ value $(3.3 \pm 0.2)$ for these kind of substrates but not suitable for the methanogenic step of $\mathrm{AD}$ (Kim et al., 2004). Values in the range of 3.0 to 6.5 were reported in the literature for the $\mathrm{pH}$ of whey (Escalante et al., 2018; Mostafa-Imeni et al., 2019). The TS content of whey $\left(57.3 \pm 3.8 \mathrm{~g} \mathrm{~kg}^{-1}\right)$ was in accordance with that reported in the literature (Mostafa-Imeni et al., 2019). The organic fraction represented 
by VS/TS was $89.7 \pm 3.8 \%$, indicating the high organic content of the substrate. C/N ratio was 15 , indicating the high nitrogen content of the whey, but also the lactose content, which is an inherited characteristic of the substrate. It is worth mentioning that several authors have pointed out a higher cheese whey C/N ratio (Carvalho et al., 2013; Vivekanand et al., 2018).

Both substrates (SGSB and whey) were highly biodegradable. After the BMP tests carried out, biodegradability values higher than $93 \%$ were observed for the different substrates and mixtures tested. The $100 \%$ SGSB presented a biodegradability of $94.2 \%$; the $85 \%$ SGSB-15\% whey, $90 \%$ SGSB-10\% whey and 95\% SGSB-5\% whey mixtures presented a biodegradability of 95.5, 94.8 and $93.9 \%$, respectively. The $100 \%$ whey substrate, the most biodegradable one, showed a biodegradability of $99.6 \%$.

The inoculum presented a $\mathrm{pH}$ of $7.2 \pm 0.1$, this value is within the acceptable range reported in the literature for anaerobic digestion processes (6.6 to 7.9) (Carvalho et al., 2019). The TS content of the inoculum was $22.7 \pm 1.8 \mathrm{~g} \mathrm{~kg}^{-1}$, which was very similar to other data available in the literature (Carvalho et al., 2019). The $\mathrm{C} / \mathrm{N}$ ratio of the inoculum (7.7) was within the previously reported range. A low inoculum $\mathrm{C} / \mathrm{N}$ ratio helps to optimize the $\mathrm{C} / \mathrm{N}$ ratio balance in the reactor when the substrates are added (Carvalho et al., 2019).

\subsection{Ammonia inhibition}

Protein-rich wastes have been described as limiting the AD process despite having a high organic load and high biodegradability. This limitation is mainly due to the fact that the rapid protein degradation leads to the formation of ammonia, which finally causes instability and/or process inhibition in the anaerobic reactor and, therefore, a 
lower biogas production (Adamietz et al., 2019; Costamagna et al., 2020). Whey is a protein-rich by-product which has an unbalanced $\mathrm{C} / \mathrm{N}$ ratio (15), so the $\mathrm{AD}$ process is usually inhibited by the production of free ammonia (Kozłowski et al., 2016). The final $\mathrm{pH}$ inside the reactors was measured with the aim of assessing the stability of the process and, simultaneously, knowing the final concentration of one of the main inhibitors of the AD methanogenic step (free ammonia) (Li et al., 2016). The TAN concentration was also measured. The final concentration of free ammonia was calculated according to equation (1).

The reactor's $\mathrm{pH}$ ranged between 7.55 and 7.78 at the end of the BMP tests (Table 2). These $\mathrm{pH}$ ranges are considered optimal for the AD process (Wei et al., 2020). The lowest TAN concentration was found in the reactor where SGSB was added as the sole substrate ( $\mathrm{C} / \mathrm{N}$ ratio: 21$)$, while TAN concentration was higher when the amount of added whey added was increased (Table 2). The TAN concentration for the AD of the SGSB alone was $1,436 \pm 17 \mathrm{mg} \mathrm{L}^{-1}$; for the mixture $95 \%$ SGSB-5\% whey the TAN concentration was $1,637 \pm 12 \mathrm{mg} \mathrm{L}^{-1}$, a value near the limit established in previous literature as toxic for the methanogenic step (Yenigün and Demirel, 2013). When the concentration of whey was $10 \%$ (mixture $90 \%$ SGSB-10\% whey), the TAN concentration $\left(1,710 \pm 21 \mathrm{mg} \mathrm{L}^{-1}\right)$ was slightly above the toxic limit established by Yenigün and Demirel (2013). The TAN concentration at the end of the experiment for the mixture $85 \%$ SGSB-15\% whey was $1,820 \pm 30 \mathrm{mg} \mathrm{L}^{-1}$; while the maximum concentration of TAN was observed when the whey was digested as a sole substrate $\left(1,844 \pm 17 \mathrm{mg} \mathrm{L}^{-1}\right)$. It is interesting to notice that an antagonistic effect on TAN inhibition has been related to minerals in the phosphorite ore $\left(\mathrm{K}^{+}, \mathrm{Ca}^{2+}, \mathrm{Mg}^{2+}\right)$. Hence, the presence of high amounts of $\mathrm{K}^{+}$can play a positive role in reducing the ammonia inhibition (Riggio et al., 2017), an important consideration for the anaerobic digester 
treating spent bedding (SGSB), which is naturally rich in both compounds. This fact can explain the lowest value of TAN found in the reactor treating $100 \%$ SGSB. On the other hand, although free ammonia is necessary for bacterial growth at concentrations below $150 \mathrm{mg} \mathrm{L}^{-1}$ (Karthikeyan and Visvanathan, 2013), at high concentrations, it may inhibit microorganism activity due to its capacity to penetrate into the microbial cell. The calculated concentration of free ammonia was similar in all the reactors, except for the reactor that digests whey as the sole substrate. The free ammonia concentration was $31.4 \mathrm{mg} \mathrm{L}^{-1}$ for the reactor that processed $100 \% \mathrm{SGSB}$ as sole substrate, $29.9 \mathrm{mg} \mathrm{L}^{-1}$ for the mixture $95 \%$ SGSB- 5\% whey and 31.9 and $31.8 \mathrm{mg} \mathrm{L}^{-1}$ for the mixtures $90 \%$ SGSB- $10 \%$ whey and $85 \%$ SGSB- $15 \%$ whey, respectively. On the other hand, the free ammonia concentration increased up to $54.0 \mathrm{mg} \mathrm{L}^{-1}$ in the reactor processing $100 \%$ whey. This ammonia concentration was lower than the toxic limit established by Yenigün and Demirel (2013) (150 $\mathrm{mg} \mathrm{L}^{-1}$ ) for completely inhibitory to $\mathrm{AD}$, indicating that although whey AD was somewhat inhibited, the free ammonia concentration was not a cause of total methanogenesis inhibition.

Table 2. Chemical composition of the biochemical methane potential (BMP) test effluents.

\begin{tabular}{ccccc}
\hline $\begin{array}{c}\text { SGSB } \\
(\%)\end{array}$ & $\begin{array}{c}\text { Whey** } \\
(\%)\end{array}$ & $\mathbf{p H}$ & $\begin{array}{c}\text { ammonium } \\
\left(\mathrm{mg} \mathrm{L}^{-1}\right)\end{array}$ & $\begin{array}{c}\text { ammonia } \\
\left(\mathrm{mg} \mathrm{L}^{-1}\right)\end{array}$ \\
\hline 100 & 0 & 7.65 & $1,436 \pm 17$ & 31.4 \\
95 & 5 & 7.57 & $1,637 \pm 12$ & 29.9 \\
90 & 10 & 7.58 & $1,710 \pm 21$ & 31.9 \\
85 & 15 & 7.55 & $1,820 \pm 30$ & 31.8 \\
0 & 100 & 7.78 & $1,844 \pm 17$ & 54.0 \\
\hline
\end{tabular}

* SGSB: Spent goat straw bedding; ** Whey: semi-soft goat cheese whey

\subsection{Production of biomethane}


The cumulative methane production of the $100 \%$ SGSB, $100 \%$ whey and the different co-digestion mixtures during 30 days digestion time are illustrated in Figure 1. As can be seen the anaerobic co-digestion of SGSB with whey did not show positive synergies in any of the mixtures analyzed. In fact, the maximum methane yield was obtained in the SGSB mono-digestion $\left(423 \pm 7 \mathrm{~mL} \mathrm{CH}_{4} \mathrm{~g}^{-1} \mathrm{VS}\right)$ when the $\mathrm{C} / \mathrm{N}$ ratio was optimal for $\mathrm{AD}$ (21). Previous studies indicate that the optimal $\mathrm{C} / \mathrm{N}$ ratio for the $\mathrm{AD}$ process is within the range of 20 and 30 (Yan et al., 2015). Carbon helps to give energy to the AD microorganisms whereas nitrogen is necessary for the growth of the microbial population. Despite this, some authors have described suitable applications at $\mathrm{C} / \mathrm{N}$ ratios well above the optimal range (Guarino et al., 2016). A BMP value of $227 \pm 8 \mathrm{~mL} \mathrm{CH}_{4} \mathrm{~g}^{-}$ ${ }^{1}$ VS was reported by Riggio et al. (2017) in the mesophilic anaerobic digestion of SGSB in a batch leach-bed reactor. So far, no other authors investigated the AD of SGSB. Therefore, due to the lack of information, the methane yield of the SGSB obtained in the present work was compared to those obtained for different anaerobic codigestions of goat manure and straw previously reported in literature. Arici and Koçar (2015) obtained a methane yield of $215.2 \mathrm{~mL} \mathrm{CH}_{4} \mathrm{~g}^{-1} \mathrm{VS}_{\text {added }}$ in the anaerobic codigestion of goat manure and maize silage. The addition of a carbon-rich substrate increased methane production and improved digestion behavior for waste utilization. When only the goat manure was used as substrate a value of $159 \mathrm{~mL} \mathrm{CH}_{4} \mathrm{~g}^{-1}$ VS was reached (Kafle and Chen, 2016). Both methane yield values were much lower than that obtained in the present research.

The production of methane from whey gave the lowest value (274 $\left.\pm 2 \mathrm{~mL} \mathrm{CH}_{4} \mathrm{~g}^{-1} \mathrm{VS}\right)$. Figure 1 shows that the methane yield increased until day 11 and then there was a lag phase of low or no methane production. Similar results were reported by Mainardis et al. (2019), which found a similar BMP value that was reached in less than 10 days, 
indicating a fast hydrolysis, as well as good adaptation of anaerobic sludge to the substrate. The rapid rise in methane production during whey AD was due to small sugar and low molecular weight protein methanization, which were easily assimilated by bacteria (Carlini et al., 2015). Whey was the used substrate with the lowest $\mathrm{C} / \mathrm{N}$ ratio (15) and TAN inhibition was also observed in the AD of this individual waste (Table 2). The methane yield value for whey $(100 \%)$ was slight higher than those obtained by Jasko et al. (2011), who reported methane yields from 136.6 to $216.3 \mathrm{~mL} \mathrm{CH}_{4} \mathrm{~g}^{-1} \mathrm{VS}$ for the AD of goat cheese whey and Gameiro et al. (2020) who reported methane yields values of $116.9 \mathrm{~mL} \mathrm{CH}_{4} \mathrm{~g}^{-1} \mathrm{VS}$. However, higher methane yields from fat whey, if compared to the actual ones, were achieved by Mainardis et al. (2019), who reported values in the range of 429.7-437.3 $\mathrm{NmL} \mathrm{CH}_{4} \mathrm{~g}^{-1} \mathrm{VS}_{\text {added. }}$. Intermediate yield values were reached for the different co-digestion mixtures. In this sense, the methane yield obtained during the co-digestion mixture of $90 \%$ SGSB-10\% whey was $371 \pm 2 \mathrm{~mL} \mathrm{CH}_{4} \mathrm{~g}^{-1} \mathrm{VS}$ and lower values were obtained for the co-digestion mixtures 95\% SGSB-5\% whey (354 $\left.\pm 27 \mathrm{~mL} \mathrm{CH}_{4} \mathrm{~g}^{-1} \mathrm{VS}\right)$ and 85\% SGSB-15\% whey $\left(293 \pm 0 \mathrm{~mL} \mathrm{CH}_{4} \mathrm{~g}^{-1} \mathrm{VS}\right)$. In these cases, co-digestion did not lead to an enhanced methane production than the methane production of single substrate digestion (SGSB), but co-digestion is a proper tool for the degradation and energy production of pollutant substrates such as whey. 


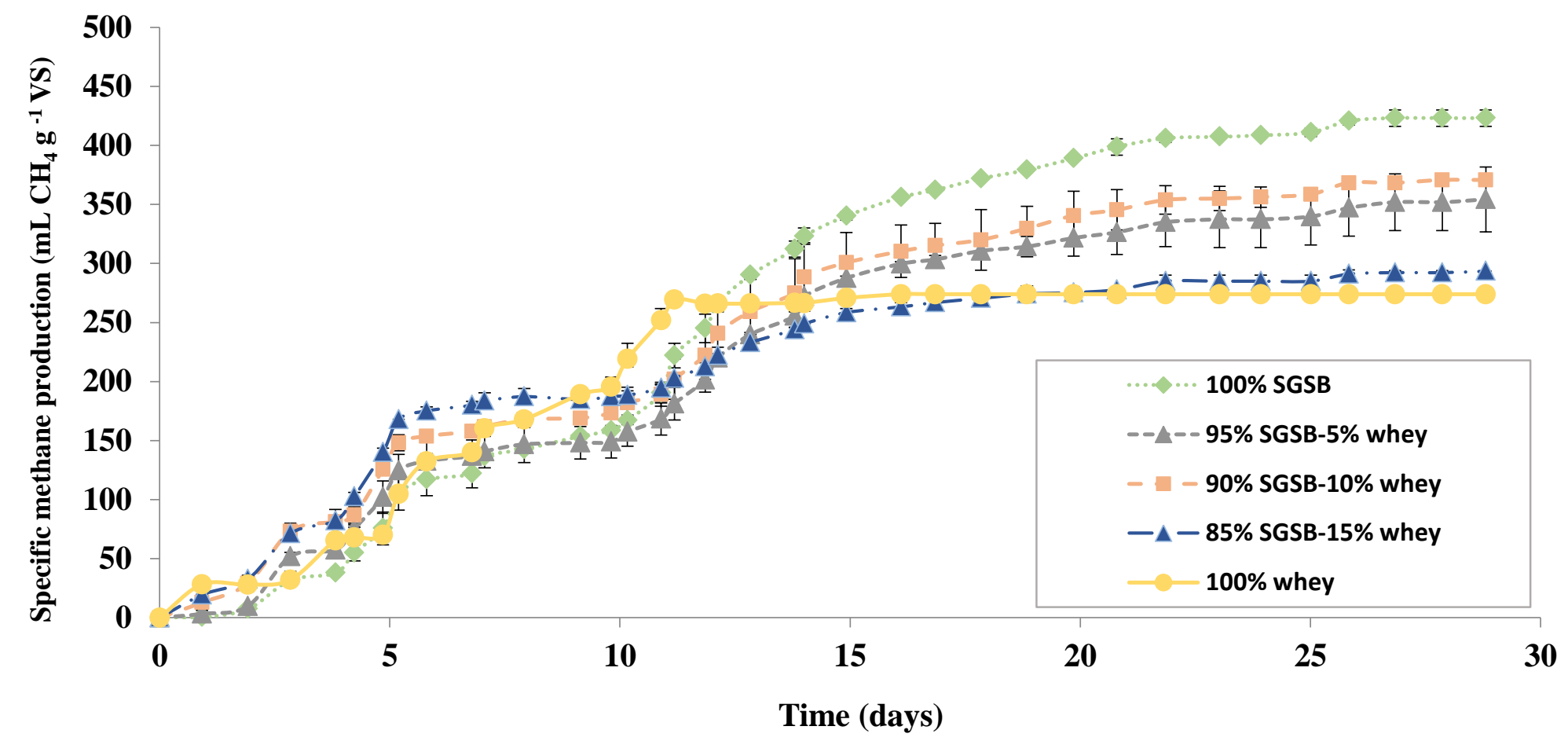

Figure 1. Variation in methane production with time in the BMP tests of the different mixtures of Spent Goat Straw Bedding (SGSB) and goat cheese whey (whey) and of both substrates individually. 


\subsection{Kinetic study}

The cumulative methane productions for the different substrates tested are recorded in Figure 1 . In the first 5 days of digestion ( $1^{\text {st }}$ stage $)$ the methane produced was scarce in all cases tested. Between the $5^{\text {th }}$ and $30^{\text {th }}$ day a typical sigmoidal or logistic curve was observed with an initial lag phase followed by a second phase, in which the methane production rate increased gradually to become almost zero after 25-28 days of digestion. The lag stage varied between 3 and 6 days depending on the substrate assayed.

With the aim of simulating the different periods of methane production during BMP test of $100 \%$ SGSB, $100 \%$ whey and the different co-digestion mixtures, two different models were selected and applied. A sigmoidal or logistic model with its three characteristic phases, i.e. lag, exponential increase and final stabilization step (Li et al., 2012); and a two-substrate model to take into account the presence and contribution of both rapidly and slowly biodegradable fractions (Bai et al., 2016; Scarcelli et al., 2020).

\subsubsection{Sigmoidal or logistic model}

The appearance of the methane production curves with repect the time allow to fit a sigmoidal or logistic model (4 parameters) with the aim of acquiring the representative kinetic parameters (Donoso-Bravo et al., 2010; Fernández-Rodríguez et al., 2014; Vats et al., 2019).

A presumption of the logistic model is that microorganism's activity is proportional to the rate of methane production (Altas, 2009). As can be seen in Figure 1, the logistic model fits the methane production during the second stage (5-30 days): an initial lag period followed by an exponential increase and a final stabilization at a maximal production level were observed. The logistic model has been already used for 
determining the methane production in BMP test of different substrates such as landfill leachate, herbaceous grass materials, sewage sludge, etc. (Pommier et al., 2007; Altas, 2009; Li et al., 2012).

Table 3 summarizes the kinetic parameters obtained from the logistic model in the BMP tests of the different mixtures and individual substrates tested. The $\mathrm{R}^{2}$ values were higher than 0.987 in all cases (Table 3). Likewise, the low values of the errors (differences between the experimental methane productions and those predicted by the model) and standard errors of estimates also indicated a good fit of the experimental data to this proposed model in all cases tested (Table 3). Figure 2 shows the experimental points of methane production versus time in the same plot as well as the theoretical curve predicted by the sigmoidal model for some of the different substrates and mixtures tested. The good fit of the data indicated that the model perfectly predicted the experimental data.

Table 3: Values of the parameters obtained from the sigmoidal 4-parameters model for the different substrates studied.

\begin{tabular}{|c|c|c|c|c|c|c|}
\hline Substrate & $\begin{array}{c}P \\
\left(\mathrm{~mL} \mathrm{CH}_{4} \mathrm{~g}^{-1}\right. \\
\mathrm{VS})\end{array}$ & $\begin{array}{c}R_{m} \\
\left(\mathrm{~mL} \mathrm{CH} \mathrm{CH}_{4}\right. \\
\left.\mathrm{g}^{-1} \mathrm{VS} \mathrm{d}^{-1}\right)\end{array}$ & $\begin{array}{l}\text { K } \\
\text { (d) }\end{array}$ & $\mathbf{R}^{2}$ & S.E.E.* & $\begin{array}{l}\text { Error** } \\
(\%)\end{array}$ \\
\hline $100 \%$ SGSB & $411 \pm 11$ & $34.7 \pm 1.5$ & 12.2 & 0.9956 & 11.37 & 0.4 \\
\hline 95\% SGSB-5 \% whey & $340 \pm 8$ & $26.8 \pm 1.3$ & 12.9 & 0.9941 & 9.43 & 3.9 \\
\hline $90 \%$ SGSB-10\% whey & $361 \pm 10$ & $22.8 \pm 1.6$ & 12.9 & 0.9937 & 9.50 & 2.7 \\
\hline
\end{tabular}


SGSB: Spent Goat Straw Bedding.

*S.E.E.: Standard error of estimate.

$* *$ Error $\left(\left(B_{m}\right.\right.$ experimental $-B_{m}$ model $) / B_{m}$ experimental $) \cdot 100$

The highest maximum methane production rate $\left(R_{m}\right)$ was achieved by the $100 \%$ SGSB with $34.7 \pm 1.5 \mathrm{~mL} \mathrm{CH}_{4} \mathrm{~g}^{-1} \mathrm{VS} \cdot \mathrm{d}^{-1}$, followed by the $100 \%$ whey substrate with $31.2 \pm$ $3.2 \mathrm{~mL} \mathrm{CH}_{4} \mathrm{~g}^{-1} \mathrm{VS} \cdot \mathrm{d}^{-1}$. The three mixtures subjected to co-digestion presented lower $R_{m}$ values with respect to the raw materials or individual substrates used. In this manner, $R_{m}$ values of $26.8 \pm 1.3,22.8 \pm 1.6$ and $14.1 \pm 0.9 \mathrm{~mL} \mathrm{CH}_{4} \mathrm{~g}^{-1} \mathrm{VS} \cdot \mathrm{d}^{-1}$ were obtained for the substrates 95\% SGSB-5\% whey, 90\% SGSB-10\% whey and 85\% SGSB-15\% whey, respectively. To be specific, a decrease in the maximum methane production rate $\left(R_{m}\right)$ from 34.7 to $14.1 \mathrm{~mL} \mathrm{CH} \mathrm{g}^{-1} \mathrm{VS} \cdot \mathrm{d}^{-1}$ was achieved because the part of whey in the mixture increased from 0 to $15 \%$. 
$100 \%$ SCSB

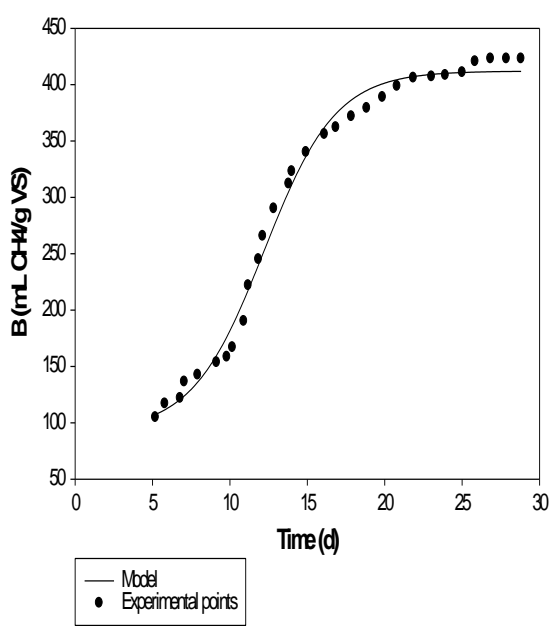

$90 \%$ SCSB $10 \%$ whey

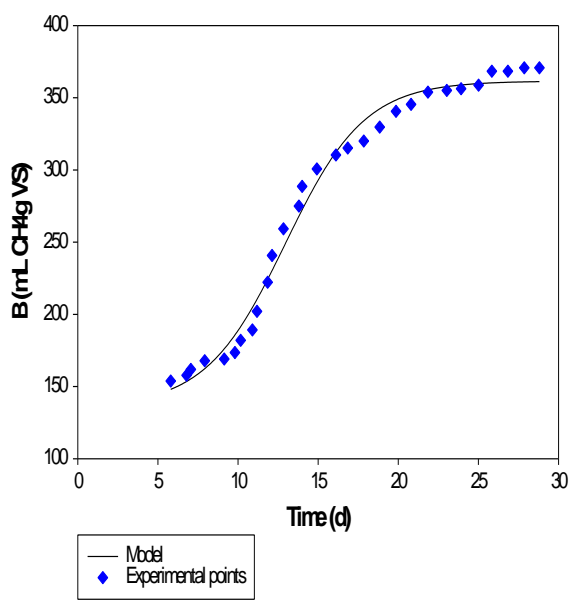

95\%SCBS.5\%whey

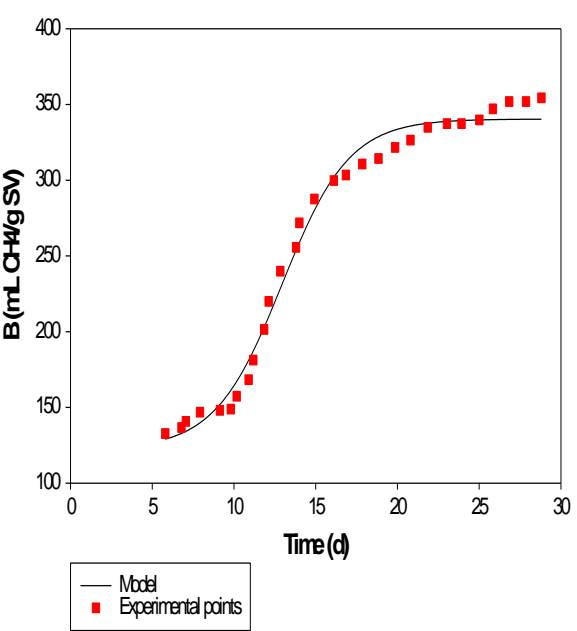

60\%0J00- 10\%WIEy

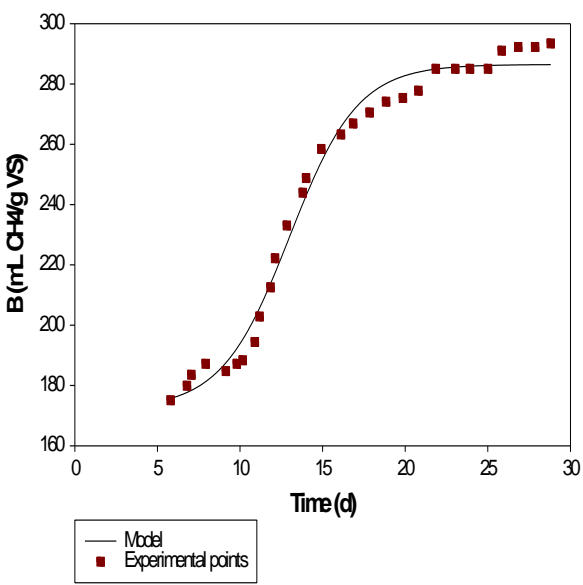

Figure 2. Variation in the experimental methane production with time (points) as well as the theoretical curve (solid lines) predicted by the logistic model for some of the cases tested.

The ammonia release during the co-digestion of increased concentrations of whey, due to the high concentrations of proteins of this substrate, could explain the poorer digestion performance and slower kinetics when the percentages of whey in the codigestion mixture were increased. 
On the other hand, the $R_{m}$ value of the $100 \%$ SGSB $\left(34.7 \mathrm{~mL} \mathrm{CH}_{4} \mathrm{~g}^{-1} \mathrm{VS} \cdot \mathrm{d}^{-1}\right)$ was of the same order of magnitude as those observed in batch AD tests of strawberry and raspberry extrudates (38 and $41 \quad \mathrm{~mL} \quad \mathrm{CH}_{4} \mathrm{~g}^{-1} \mathrm{VS} \cdot \mathrm{d}^{-1}$, respectively), substrates characterized by a high content of carbohydrates (14-267 $\mathrm{mg}$ glucose $\mathrm{g}^{-1} \mathrm{VS}$ ) and appropriate $\mathrm{C} / \mathrm{N}$ ratios (24 and 27) (Trujillo-Reyes et al., 2019).

In addition, the lowest value of the maximum methane production predicted by the model, $P$, was found for $100 \%$ whey $\left(274 \pm 10 \mathrm{~mL} \mathrm{CH}_{4} \mathrm{~g}^{-1} \mathrm{VS}\right)$, which showed an unbalanced $\mathrm{C} / \mathrm{N}$ ratio (15), far from the optimum $\mathrm{C} / \mathrm{N}$ ratio for $\mathrm{AD}$ (20-30). By contrast, the highest $P$ value was found for $100 \%$ SGSB $\left(411 \pm 11 \mathrm{~mL} \mathrm{CH}_{4} \mathrm{~g}^{-1} \mathrm{VS}\right)$, the substrate which achieved the greatest $\mathrm{C} / \mathrm{N}$ ratio (21). Previous studies have informed that $\mathrm{C} / \mathrm{N}$ ratios lower than 20/1 lead to potential inhibition due do the presence of free ammonia; in contrast $\mathrm{C} / \mathrm{N}$ ratios higher than 30/1 could cause nitrogen limitations (Sialve et al., 2009). In fact, the proper SGSB is really a mixture of two substrates, goat manure and straw bedding, which benefits the overall AD process for a substrate with high nitrogen content such as goat manure to be digested with another with high organic content such as spent straw. As is well known, the benefits of co-digestion lie in balancing the $\mathrm{C} / \mathrm{N}$ ratio in the co-substrate mixture, as well as macro and micronutrients, $\mathrm{pH}$, inhibitors/toxic compounds and dry matter. Anaerobic co-digestion is increasingly being used as an alternative to treat different agro-industrial waste. Anaerobic co-digestion also helps to use reactors more efficiently, as well as costs by processing different waste streams in a single piece of equipment (Imeni et al., 2019).

\subsubsection{Two-substrates kinetic model}


The kinetic parameters got from the two-substrate model in the batch anaerobic assays of the different mixtures and individual substrates tested are resumed in Table 4 . The $\mathrm{R}^{2}$ values were higher than 0.981 in all cases and the low values of the standard errors of the estimates also specified a well-suited of the experimental data to this proposed model in all cases studied (Table 4).

As can be seen in Table 4, the maximum methane production values of the rapid $\left(B_{\text {rapid }}\right)$ and slow $\left(B_{\text {slow }}\right)$ stages were very similar in all cases studied, showing no significant differences. By contrast, higher differences between the $B_{\text {rapid }}$ and $B_{\text {slow }}$ stage were found when microalgae and waste activated sludge mixtures were co-digested anaerobically (Scarcelli et al., 2020). In addition, the lowest value for the maximum methane production predicted by the model for both stages, $\left(B_{\text {rapid }}\right.$ and $\left.B_{\text {slow }}\right)$, was found for $100 \%$ whey $\left(152 \pm 8\right.$ and $162 \pm 5 \mathrm{~mL} \mathrm{CH}_{4} \mathrm{~g}^{-1} \mathrm{VS}$, respectively), which could be attributed to a low and unbalanced $\mathrm{C} / \mathrm{N}$ ratio (15), far from the optimum $\mathrm{C} / \mathrm{N}$ ratio for AD (20-30). As was previously stated, C/N ratios lower than 20/1 can cause an inhibition in the anaerobic process due do the presence of free ammonia (Sialve et al., 2009). By contrast, the highest $B_{\text {rapid }}$ and $B_{\text {slow }}$ values were found for $100 \%$ SGSB (403 \pm 5 and $405 \pm 2 \mathrm{~mL} \mathrm{CH}_{4} \mathrm{~g}^{-1} \mathrm{VS}$, respectively), the substrate that achieved the greatest $\mathrm{C} / \mathrm{N}$ ratio (21), a value within the optimum ratio for an adequate performance of the $\mathrm{AD}$ processes. In relation to the hydrolysis kinetic constants, an increase in its value for the rapid biodegradation stage $\left(k_{\text {rapid }}\right)$ was observed when compared to the value found for the slow $\left(k_{\text {slow }}\right)$ biodegradation stage. In this way, increases (or differences) between these two kinetic constants of $5 \%, 8 \%, 15 \%, 26 \%$ and $42 \%$ were obtained for $100 \%$ SGSB, 95\% SGSB-5\% whey, 90\% SGSB-10\% whey, 85\% SGSB-15\% whey, and $100 \%$ whey, respectively. As can be seen the differences between both constants for 100\% SGSB and 95\% SGSB-5\% whey were not statistically significant. In addition, a 
decrease in the values of both kinetic constants was observed when the percentage of whey in the mixture increased from 0 to $100 \%$. The ammonia release during the codigestion of increased concentrations of whey, due to the high concentrations of proteins in this substrate, could explain the lower kinetic constants found when the percentages of whey in the co-digestion mixtures were greater. The maximum methane production rates $\left(R_{m}\right)$ calculated from the sigmoidal model follow the same trend.

This same increase in the values of the kinetic constant of the rapidly biodegradable fraction compared to the values for the slowly biodegradable fraction was also recently observed during the anaerobic co-digestion of different mixtures of microalgae and waste activated sludge (WAS) and the digestion of both substrates individually. As examples, the values of $k_{\text {rapid }}$ and $k_{\text {slow }}$ of 1.116 and $0.037 \mathrm{~d}^{-1}, 0.846$ and $0.027 \mathrm{~d}^{-1}, 0.717$ and $0.028 \mathrm{~d}^{-1}, 0.764$ and $0.026 \mathrm{~d}^{-1}$ were obtained for 100\% microalgae, 80:20, 60:40 and 40:60\% of microalgae and WAS, respectively (Scarcelli et al., 2020).

Table 4: Values of the parameters obtained from the two-substrate model for the different wastes studied $\left(B=B_{\text {rapid }}\left[1-\exp \left(-k_{\text {rapid }} * t\right)\right]+B_{\text {slow }}\left[1-\exp \left(-k_{\text {slow }} * t\right)\right]\right)$

\begin{tabular}{ccccccc}
\hline Substrate & $B_{\text {rapid }}$ & $B_{\text {slow }}$ & $k_{\text {apid }}$ & $k_{\text {slow }}$ & $\mathbf{R}^{2}$ & S.E.E.* \\
& $\left(\mathrm{mL} \mathrm{CH}_{4} \mathrm{~g}^{-1}\right.$ & $\left(\mathrm{mL} \mathrm{CH}_{4} \mathrm{~g}^{-1}\right.$ & $\left(\right.$ days $\left.^{-1}\right)$ & $\left(\right.$ days $\left.^{-1}\right)$ & & \\
VS $)$ & VS $)$ & & &
\end{tabular}

$100 \%$ SGSB

$403+5$

$405 \pm 2$

0.148

0.141

0.986

13.51 
$85 \%$ SGSB- $15 \%$ whey

A two-substrate model was also used to describe the apparent presence of rapid and slowly degradable material in the AD of algal biomass previously pre-treated with free nitrous acid (FNA). A model-based analysis revealed that with FNA pre-treatment (2.31 mg $\mathrm{HNO}_{2}-\mathrm{N} \mathrm{L}^{-1}$ ), the availability of both rapid and slowly biodegradable substrates were increased (Bai et al., 2016). In this sense, for the above-mentioned pre-treatment, the kinetic constants of the slowly and rapidly biodegradable fractions were $0.01 \pm 0.02$ and $0.22 \pm 0.03 \mathrm{~d}^{-1}$, respectively. The kinetic constants of the slowly and rapidly biodegradable fractions showed the same trend than that observed in the present work.

Spent goat straw bedding (SGSB) is a valuable resource for green energy production in rural areas. This research showed that SGSB is a promising substrate for anaerobic digestion and its digestion as sole substrate is feasible. Moreover, the results derived from this study suggest that a co-digestion with a more easily degradable substrate like cheese whey could be done. Further, the modelling work described based on the experimental results achieved can help further optimize the bioprocess of converting goat by-products into renewable energy. Valorisation of organic waste streams into bioenergy represents a major opportunity for securing sustainable energy production in all regions of the world. Scientific studies such as this one, which seek to improve existing 
anaerobic digestion technology, will play a key role in helping achieve a sustainable energy future. This research work will be completed in the future with anaerobic digestion studies of these substrates carried out in continuous mode to obtain key parameters that allow the set-up and optimization of full-scale anaerobic plants.

\section{CONCLUSIONS}

Spent goat straw bedding (SGSB) is a promising substrate for a farm-scale anaerobic plant and its digestion as sole substrate is feasible. Moreover, the overall process stability suggests that a co-digestion with another easily degradable substrate, i.e. whey, could be done. The BMP values for SGSB, whey and different mixtures of both were measured in the range of 423-274 $\mathrm{mL} \mathrm{CH}_{4} \mathrm{~g}^{-1} \mathrm{VS}$. Data from the anaerobic digestion of different mixtures of SGSB and whey and of both substrates individually were well described by a logistic and a two-substrate model. The logistic or sigmoidal model (4 parameters) demonstrated that the maximum methane production rate decreased when the amount of whey in the mixture increased. The two-substrate model indicated that in the mono and co-digestions of these substrates it is necessary to take into account the contribution of both rapidly and slowly biodegradable fractions.

\section{ACKNOWLEDGMENTS}

The authors wish to thank to the regional government of Andalucía, Junta de Andalucía, Consejería de Economía y Conocimiento (Project of Excellence RNM-1970) for providing financial support. N.F. Puntano also wishes to thank the academic mobility and exchange program (PIMA). The PIMA program is a mobility initiative for 
undergraduate students promoted by the Ibero-American States Organization. The authors also wish especially to thank Manuel Vázquez (Sierra del Romero) for his contribution.

\section{REFERENCES}

Ahmad, T., Aadil, R.M., Ahmed, H., Rahman, U., Soares, B.C.V., Souza, S.L.Q., Pimentel, T.C., Scudino, H., Guimarães, J.T., Esmerino, E.A., Freitas, M.Q., Almada, R.B., Vendramel, S.M.R., Silva, M.C., \& Cruz, A.G. (2019). Treatment and utilization of dairy industrial waste: A review. Trends in Food \& Science Technology, 88, 361-372. https://doi.org/10.1016/j.tifs.2019.04.003

Adamietz, T., Jurkowski, W., Adolph, J., \& Brück, T. B. (2019). Biogas yields and composition from oil-extracted halophilic algae residues in conventional biogas plants operated at high salinities. Bioprocess and Biosystems Engineering, 42(12), 1915-1922. doi:10.1007/s00449-019-02185-8

Altas, L. (2009). Inhibitory effect of heavy metals on methane-producing anaerobic granular sludge. Journal of Hazardous Materials, 162 (2-3), 1551-1556. https://doi.org/10.1016/j.jhazmat.2008.06.048

APHA, AWWA, WEF, (2012). Standard Methods for examination of water and wastewater. 22nd ed. Washington: American Public Health Association, pp. 1360 ISBN 978-087553-013-0

Arici, Ş. \& Koçar, G. (2015). The Effect of Adding Maize Silage as a Co-Substrate for Anaerobic Animal Manure Digestion. International Journal of Green Energy. 12 (5), 453-460. https://doi.org/10.1080/15435075.2013.848361 
Awodun, M.A., Omonijo, L.I., \& Ojeniyi, S.O. (2007). Effect of goat dung and NPK fertilizer on soil and leaf nutrient content, growth and yield of pepper. Journal Soil Science, 2(2), 142-147.9

Bai, X., Lant, P.A., Jensen, P.D., Astals, S., \& Pratt, S. (2016). Enhanced methane production from algal digestion using free nitrous acid pre-treatment. Renewable Energy, 88, 383-390. https://doi.org/10.1016/j.renene.2015.11.054

Carlini, M., Castellucci, S., \& Moneti, M. (2015). Biogas Production from Poultry Manure and Cheese Whey Wastewater under Mesophilic Conditions in Batch $\begin{array}{llll}\text { Reactor. } & \text { Energy } & \text { Procedia, } & 82,\end{array}$ https://doi.org/10.1016/j.egypro.2015.11.817

Carvalho, F., Prazeres, A.R., \& Rivas, J. (2013). Cheese whey wastewater: Characterization and treatment. Science of the Total Environment, 445, 385-396. https://doi.org/10.1016/j.scitotenv.2012.12.038

Carvalho, A., Fragoso, R., Gominho, J., \& Duarte, E. (2019). Effect of Minimizing dLimonene Compound on Anaerobic Co-digestion Feeding Mixtures to Improve Methane Yield. Waste Biomass Valorization, 10(1), 75-83. https://doi.org/10.1007/s12649-017-0048-1

Costamagna, P., Giordano, A., Lazzarini, Y., Delucchi, M., \& Busca, G. (2020). Process of ammonia removal from anaerobic digestion and associated ammonium sulphate production: Pilot plant demonstration. Journal of Environmental Management, 259. https://doi.org/ 10.1016/j.jenvman.2019.109841

De Corato, U. (2020). Agricultural waste recycling in horticultural intensive farming systems by on-farm composting and compost-based tea application improves soil quality and plant health: A review under the perspective of a circular 
economy. Science of the Total Environment, 783.

https://doi.org/10.1016/j.scitotenv.2020.139840

Donoso-Bravo, A., Perez-Elvira, S.I., \& Fernández-Polanco, F. (2010). Application of simplified models for anaerobic biodegradability tests. Evaluation of pretreatment processes. Chemical Engineering Journal, 160, 607-614. https://doi.org/10.1016/j.cej.2010.03.082

Duque-Acevedo, M., Belmonte-Ureña, L.J., Plaza-Úbeda, J.A., \& Camacho-Ferre, F. (2020). The Management of Agricultural Waste Biomass in the Framework of Circular Economy and Bioeconomy: An Opportunity for Greenhouse Agriculture in Southeast Spain. Agronomy, 10(4), 489.

Escalante, H., Castro, L., Amaya, M.P., Jaimes, L., \& Jaimes-Estévez, J. (2018). Anaerobic digestion of cheese whey: Energetic and nutritional potential for the dairy sector in developing countries. Waste Management, 71, 711-718. https://doi.org/10.1016/j.wasman.2017.09.026

Feng, L., Ward, A. J., Guixé, P. G., Moset, V., \& Møller, H. B. (2018). Flexible biogas production by pulse feeding maize silage or briquetted meadow grass into continuous stirred tank reactors. Biosystems Engineering, 174, 239-248. https://doi.org/10.1016/j.biosystemseng.2018.07.013

Fernández-Rodríguez, M.J., Rincón, B., Fermoso, F.G., Jimenez, A., \& Borja, R. (2014). Assessment of two-phase olive mil solid waste and microalgae co-digestion to improve methane production and process kinetics. Bioresource Technology, 157, 263-269. https://doi.org/10.1016/j.biortech.2014.01.096

Fernández-Rodríguez, M.J., de la Lama-Calvente, D., Jiménez-Rodríguez, A., Borja, R., \& Rincón-Llorente, B. (2019). Anaerobic co-digestion of olive mill solid waste and 
microalga Scenedesmus quadricauda: effect of different carbon to nitrogen ratios on process performance and kinetics. Journal of Applied Phycology, 31(6), 35833591. https://doi.org/10.1007/s10811-019-01858-x

Foley, J.A., Ramankutty, N., Brauman, K.A., Cassidy, E.S., Gerber, J.S., Johnston, M., Mueller, N.D., O’Connell, C., Ray, D.K., West, P.C., Balzer, C., Bennett, E.M., Carpenter, S.R., Hill, J., Monfreda, C., Polasky, S., Rockström, J., Sheehan, J., Siebert, S., Tilman, D., \& Zaks, D.P.M. (2011). Solutions for a cultivated planet. Nature. 478 (7369), 337-342. https://doi.org/10.1038/nature10452

Fox, P.F., Guinee, T.P., Cogan, T.M., \& McSweeney, P.L. (2017). Whey and whey products. In Fundamentals of cheese science. Springer, Boston, MA. pp.755-769.

Gameiro, T., Novais, R. M., Correia, C. L., Carvalheiras, J., Seabra, M. P., Labrincha, J. A., Duarte, A.C., \& Capela, I. (2020). Red mud-based inorganic polymer spheres: Innovative and environmentally friendly anaerobic digestion enhancers. $\begin{array}{llll}\text { Bioresource } & \text { Technology, } & 323904 .\end{array}$ https://doi.org/10.1016/j.biortech.2020.123904

Guarino, G., Carotenuto, C., Di Cristofaro, F., Papa, S., Morrone, B., \& Minale, M. (2016). Does the $\mathrm{C} / \mathrm{N}$ ratio really affect the Bio-methane Yield? A three Years Investigation of Buffalo Manure Digestion. Chemical Engineering Transactions, 49, 463-468. https://doi.org/10.3303/CET1649078

Holter, P. (2016). Herbivore dung as food for dung beetles: elementary coprology for entomologists. Ecological Entomology, $\quad$ 41(4), $\quad$ 67-377. https://doi.org/10.1111/een.12316 
Imeni, S.M., Pelaz, L., Corchado-Lopo, C., Busquets, A.M., Ponsá, S., \& Colon, J. (2019). Techno-economic assessment of anerobic co-digestion of livestock manure and cheese whey (cow, goat \& sheep) at small to medium dairy farms. Bioresource Technology, 291, 121872. https://doi.org/10.1016/j.biortech.2019.121872

Islam Siddique, M. N., Khalid, Z. B., \& Ibrahim, M. Z. B. (2020). Effect of additional nutrients on bio-methane production from anaerobic digestion of farming waste: Feasibility \& fertilizer recovery. Journal of Environmental Chemical Engineering, 8(1) https://doi.org/10.1016/j.jece.2019.103569

Jasko, J., Skripsts, E., Dubrovskis, V., Zabarovskis, E., \& Kotelenecs, V. (2011). Biogas production from cheese whey in two phase anaerobic digestion. Vol. 26.

Jiang, X., Chen, Z., \& Dharmasena, M. (2015). The role of animal manure in the contamination of fresh food. In Advances in microbial food safety pp. 312-350. Woodhead Publishing.

Joshi, P., \& Visvanathan, C. (2019). Sustainable management practices of food waste in asia: Technological and policy drivers. Journal of Environmental Management, 247, 538-550. https://doi.org/10.1016/j.jenvman.2019.06.079

Kafle, G. \& Chen, L. (2016). Comparison on batch anaerobic digestion of five different livestock manures and prediction of biochemical methane potential (BMP) using different statistical models. Waste Management, 48, 492-502. https://doi.org/10.1016/j.wasman.2015.10.021

Karthikeyan, O.P., \& Visvanathan, C. (2013). Bio-energy recovery from high-solid organic substrates by dry anaerobic bio-conversion processes: a review. Reviews in 
Environmental Science and Biotechnology, 12, 257-284.

https://doi.org/10.1007/s11157-012-9304-9

Kim, I., Hwang, M., Jang, N., Seong Hyun, H., \& Lee, S.T. (2004). Effect of low pH on the activity of hydrogen utilizing methanogen in bio-hydrogen process. International Journal Hydrogen Energy, 29, 1133-1140. https://doi.org/10.1016/j.ijhydene.2003.08.017

Kozłowski, K., Lewicki, A., Sołowiej, P., Neugebauer, M., \& Smurzyńska, A. (2016). Usage of whey as mono-substrate in continous fermentation process. International Multidisciplinary Scientific GeoConference : SGEM 2016. 3, 345-350.

Li, L., Kong, X., Yang, F., Li, D., Yuan, Z., \& Sun, Y. (2012). Biogas production potential and kinetics of microwave and conventional thermal pretreatment of grass. Applied Biochemistry Biotechnology, 166, 1183-1191. https://doi.org/10.1007/s12010-011-9503-9

Li, Y., Li, Y., Zhang, D., Li, G., Lu, J., \& Li, S. (2016). Solid state anaerobic codigestion of tomato residues with dairy manure and corn stover for biogas $\begin{array}{llll}\text { production. } & \text { Bioresource } & \text { Technology, } & \text { 217, }\end{array}$ https://doi.org/10.1016/j.biortech.2016.01.111

Macaskie, L.E., Sapsford, D.J., \& Mayes, W.M. (Eds.). (2019). Resource Recovery from Wastes (Vol. 63). Royal Society of Chemistry.

Macwan, S.R., Dabhi, B.K., Parmar, S.C., \& Aparnathi, K.D. (2016). Whey and its utilization. International Journal of Current Microbiology and Applied Sciences, 8, 134-155. http://dx.doi.org/10.20546/ijcmas.2016.508.016 
Mainardis, M., Cabbai, V., Zannier, G., Visintini, D., \& Goi, V. (2017). Characterization of BMP tests of liquid substrates for high-rate anaerobic digestion. Chemical and Biochemical Engineering Quarterly, 31 (4), 509-518, https://doi.org/10.15255/CABEQ.2017.1083.

Mainardis, M., Flaibani, S., Trigatti, M., \& Goi, D. (2019). Techno-economic feasibility of anaerobic digestion of cheese whey in small Italian dairies and effect of ultrasound pre-treatment on methane yield. Journal of Environmental Management, 246, 557-563. http://dx.doi.org/10.1016/j.jenvman.2019.06.014

Martínez-Sabater, E., García-Muñoz, M., Bonete, P., Rodriguez, M., Sánchez-García, F. B., Pérez-Murcia, M. D., Bustamante, M.A., López-Lluch, D.B., \& Moral, R. (2019). Comprehensive management of dog faeces: Composting versus anaerobic $\begin{array}{llll}\text { digestion. Journal of } & \text { Environmental }\end{array}$ https://doi.org/10.1016/j.jenvman.2019.109437

Mostafa-Imeni, S., Pelaz, L., Corchado-Lopo, C., Maria Busquets, A., Ponsá, S., \& Colón, J. (2019). Techno-economic assessment of anaerobic co-digestion of livestock manure and cheese whey (Cow, Goat \& Sheep) at small to medium dairy

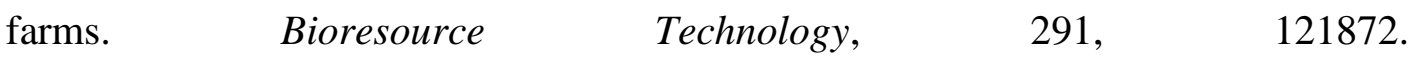
https://doi.org/10.1016/j.biortech.2019.121872

Østergaard, N. (1985). Biogasproduktion i det thermofile temperaturinterval. STUB rapport nr. 21. Kemiteknik. Dansk Teknologisk Institut. Taastrup (in Danish).

Pommier, S., Chenu, D., Quintard, M., \& Lefebvre, X. (2007). A logistic model for the prediction of the influence of water on the solid waste methanization in landfills. 
Biotechnology and Bioengineering, $97 \quad$ (3), 473-482. https://doi.org/10.1002/bit.21241

Rao, M.S., Singh, S.P., Singh, A.K. \& Sodha, M.S. (2000). Bioenergy conversion studies of the organic fraction of MSW: assessment of ultimate bioenergy production potential of municipal garbage. Applied Energy, 66, 75-87. https://doi.org/10.1016/S0306-2619(99)00056-2

Raposo, F., de la Rubia, M.A., Borja, R., \& Alaiz, M. (2008). Assessment of a modified and optimised method for determining chemical oxygen demand of solid substrates and solutions with high suspended solid content. Talanta, 76(2), 448-453. https://doi.org/10.1016/j.talanta.2008.03.030

Riggio, S., Torrijos, M., Debord, R., Esposito, G., van Hullebusch, E.D., Steyer, J.P., \& Escudié, R. (2017). Mesophilic anaerobic digestion of several types of spent livestock bedding in a batch leach-bed reactor: substrate characterization and process performance. Waste Management, 59, 129-139. https://doi.org/10.1016/j.wasman.2016.10.027

Rodrigues, M.D.S.S., \& Borges, A. (2020). Can Circular Economy Tools Improve the Sustainable Management of Industrial Waste?. In International Business, Trade and Institutional Sustainability pp. 183-200. Springer, Cham.

Rojas-Downing, M.M., Nejadhashemi, A.P., Harrigan, T., \& Woznicki, S.A. (2017). Climate change and livestock: Impacts, adaptation, and mitigation. Climate Risk Management, 16, 145-163. https://doi.org/10.1016/j.crm.2017.02.001

Sanchis-Sebastiá, M., Erdei, B., Kovacs, K., Galbe, M., \& Wallberg, O. (2020). Analysis of Animal Bedding Heterogeneity for Potential Use in Biorefineries Based 
on Farmyard Manure. Waste Biomass Valorization, 11(6), 2387-2395. https://doi.org/10.1007/s12649-018-00578-6

Scarcelli, P.G., Serejo, M.L., Paulo, P.L. \& Boncz, M.A. (2020). Evaluation of biomethanization during co-digestion of thermally pretreated microalgae and waste activated sludge, and estimation of its kinetic parameters. Science of the Total Environment, 706, 135745. https://doi.org/10.1016/j.scitotenv.2019.135745

Sialve, B., Bernet, M., \& Bernard, O. (2009). Anaerobic digestion of microalgae as a necessary step to make microalgal biodiesel sustainable. Biotechnology Advances, 27, 409-416. https://doi.org/10.1016/j.biotechadv.2009.03.001

Stahel, W.R. (2016). The circular economy. Nature, 531(7595), 435-438.

Trujillo-Reyes, A., Cubero, J., Rodríguez, G., García, J.F., Rodríguez, M., Borja, R., Serrano, A., \& Fermoso, F.G. (2019). Extraction of phenolic compounds and production of biomethane from strawberry and raspberry extrudates. Biochemical Engineering Journal, 147:11-19. https://doi.org/10.1016/j.bej.2019.03.023

United Nations Development Programme (UNDP) (2016), Goal 12 responsible consumption and production, available at: www.undp.org/content/undp/en/home/sustainable-development-goals/goal-12responsible-consumption-and-production.html

Van Kernebeek, H.R., Oosting, S.J., Van Ittersum, M.K., Bikker, P., \& De Boer, I.J. (2016). Saving land to feed a growing population: consequences for consumption of crop and livestock products. International Journal of Life Cycle Assessment, 21(5), 677-687. https://doi.org/10.1007/s11367-015-0923-6 
Van, D.P., Fujiwara, T., Leu Tho, B., Song Toan, P.P., \& Hoang Minh, G.A. (2020). Review of anaerobic digestion systems for biodegradable waste: Configurations, operating parameters, and current trends. Environmental Engineering Research, 25 (1), 1-17. https://doi.org/10.4491/eer.2018.334

Vats, N., Khan, A. A., \& Ahmad, K. (2019). Anaerobic co-digestion of thermal pretreated sugarcane bagasse using poultry waste. Journal of Environmental Chemical Engineering, 7(5) https://doi.org/10.1016/j.jece.2019.103323

Vivekanand, V., Mulat, D.G., Eijsink, V.G.H., \& Horn, S.J. (2018). Synergistic effects of anaerobic co-digestion of whey, manure and fish ensilage. Bioresource Technology, 249, 35-41. https://doi.org/10.1016/j.biortech.2017.09.169

Wei, Y., Yuan, H., Wachemo, A.C., \& Li, X. (2020). Anaerobic co-digestion of cattle manure and liquid fraction of digestate (LFD) pretreated corn stover: Pretreatment process optimization and evolution of microbial community structure. Bioresource Technology, 296, 122282. https://doi.org/10.1016/j.biortech.2019.122282

Yan, Z., Song, Z., Li, D., Yuan, Y., Liu, X., \& Zheng, T. (2015). The effects of initial substrate concentration, $\mathrm{C} / \mathrm{N}$ ratio, and temperature on solid-state anaerobic digestion from composting rice straw. Bioresource Technology, 177, 266-273. https://doi.org/10.1016/j.biortech.2014.11.089

Yenigün, O., \& Demirel, B. (2013). Ammonia inhibition in anaerobic digestion: A review. Process Biochemestry, $48 \quad$ (5-6), $\quad$ 901-911. https://doi.org/10.1016/j.procbio.2013.04.012 